\title{
Survival of Oospores of Phytophthora capsici in Soil
}

\author{
M. Babadoost and C. Pavon, Department of Crop Sciences, University of Illinois, Urbana 61801
}

\begin{abstract}
Babadoost, M., and Pavon, C. 2013. Survival of oospores of Phytophthora capsici in soil. Plant Dis. 97:1478-1483.

This study assessed survival of Phytophthora capsici oospores in soil in Illinois. Soils differing in texture and other characteristics were collected from four Illinois Counties (Champaign, Gallatin, Madison, and Tazewell), equilibrated to $-0.3 \mathrm{MPa}$, and infested with oospores of $P$. capsici at a density of $5 \times 10^{3}$ oospores/g of dry soil. Samples $(25 \mathrm{~g})$ of the infested soil were placed in $15-\mu \mathrm{m}$ mesh polyester bags, which were sealed and placed at 2-, 10-, and 25-cm depths in 15.3-cm-diameter PVC tubes containing the same field soil as the infested bags. Tubes were buried vertically in the ground at the University of Illinois Vegetable Research Farm in Champaign in October 2004. Soil samples were assayed for recovery and germination of oospores 1 day and 3, 6, $12,24,30,36$, and 48 months after incorporation of oospores into the soil. Overall, the percentage of oospore recovery and the percentage of germination of oospores were not affected significantly by soil source and burial depth but both the oospore recovery and oospore germination were significantly $(P=0.001)$ affected by the duration of oospore burial. The rate of oospore recovery from soil samples was 61.06, $16.69,10.28,1.05,0.30,0.06,0.05$, and $0.004 \%$ after 1 day and 3, 6, $12,24,30,36$, and 48 months, respectively, following incorporation of

oospores into the soil; and mean oospore germination was 47.17, $30.53,21.33,15.64,7.42,2.67,2.61$, and $0.00 \%$, respectively. Survival of $P$. capsici oospores was compared in soil samples stored in a laboratory at $22^{\circ} \mathrm{C}$ versus on the soil surface or buried 2,10 , or $25 \mathrm{~cm}$ deep in a field. Oospores were recovered 1, 3, 6, 12, and 24 months after incorporation for both storage locations. The percentage of oospores recovered from samples stored in the laboratory was significantly $(P=$ $0.004)$ greater than recovery from samples stored in the field, regardless of the depth of burial. Twenty-four months after incorporation of oospores, $26.52 \%$ of oospores were recovered from soil samples in the laboratory, whereas only $0.12 \%$ of oospores were recovered from soil samples in the field. Overall, the percentages of germination of oospores recovered from samples in the laboratory and field over 24 months were not significantly different. In both experiments, germinated oospores produced mycelia, sporangia, and zoospores, and were virulent on 'California Wonder' bell pepper. This study showed that oospores of $P$. capsici can survive and remain virulent in Illinois soils for more than 36 months but oospores were no longer viable after 48 months in soil in a field environment.
\end{abstract}

Phytophthora capsici Leonian is the causal agent of Phytophthora blight of vegetables (12). Phytophthora blight has become one of the most significant threats to cucurbit and pepper production worldwide $(5,13,14,16,23,28)$. $P$. capsici can attack the host plant at any growth stage, causing up to $100 \%$ crop losses $(2,13)$. The pathogen causes seedling death, crown rot, foliar blight, and fruit rot in cucurbits $(9,13,16,19)$ and root rot, crown rot, foliar blight, and fruit rot in pepper $(14,23,24,29)$. P. capsici can also infect other plant species in 15 families $(9,13,31)$.

P. capsici is a soilborne pathogen and survives between crops as oospores in soil $(2,9,11,13)$. Oospores are resistant to desiccation, cold temperatures, and other extreme environmental conditions, and can survive in the soil for several years in the absence of a host plant $(9,13)$. Oospores germinate and produce sporangia and zoospores. Zoospores are released in water, dispersed by irrigation or surface water, and infect plant tissues. If the environmental conditions are conducive (moist and warm), the disease develops rapidly $(13,16)$.

Although oospores have been considered the primary source of inoculum of $P$. capsici in the field, little is known about survival and viability of oospores in soil, influence of soil texture, and other physical soil factors on survival of oospores, and infection of host crops in oospore-infested soils. Several researchers have reported useful information for assessing the presence of $P$. capsici oospores in soil but a reliable procedure for evaluating viability of $P$. capsici oospores in soil has not been published. In 1981, Papavizas et al. (26) developed a semiselective medium for isolation of Phy-

Corresponding author: M. Babadoost,

E-mail: babadoos@illinois.edu

Accepted for publication 9 May 2013.

http://dx.doi.org/10.1094/PDIS-12-12-1123-RE

(C) 2013 The American Phytopathological Society tophthora spp. from soil. In 1995, Larkin et al. (22) compared available assay methods, including soil dilution plating on a selective medium and a pepper leaf disk bioassay, for recovery of $P$. capsici zoospores, sporangia, and oospores from soil. They reported that, although no single assay method was satisfactory for the accurate detection and quantification of all propagules of $P$. capsici in soil, the leaf disk assay provided the best detection for all propagule types. They found that soil dilution plating after soil sample saturation and incubation provided the best recovery of oospores. In 2008, Pavon et al. (27) published a method of using sucrose centrifugation to quantify oospores of $P$. capsici in soil, which proved to be a reliable method to evaluate the presence of $P$. capsici oospores in soil.

The objective of this study was to assess survival of $P$. capsici oospores in a vegetable field in Champaign County, IL, where Phytophthora blight occurs regularly on cucurbits and pepper (2). A preliminary report of this study was presented at the 2009 International Phytophthora capsici Conference in Duck Cay, FL (4).

\section{Materials and Methods}

In vitro oospore production. Isolates of $P$. capsici were collected from infected pumpkin and zucchini plants in Illinois in 2004. A1 (PC-81) and A2 (PC-60) mating type isolates from processing pumpkin, with high oospore production levels, were selected, and oospores were produced in 250-ml glass flasks containing $30 \mathrm{ml}$ of $\mathrm{V} 8-\mathrm{CaCO}_{3}$ broth medium (27). The flasks were incubated at $24^{\circ} \mathrm{C}$ in the dark for 2 months. Then, the oospores were harvested by blending the culture at full speed in a blender (Hamilton Beach Mo. 52250) for 90 s. The suspension in the blender was passed through 63- and 38- $\mu$ m metal sieves and a 20$\mu \mathrm{m} \mathrm{Spectra/Mesh} \mathrm{nylon} \mathrm{filter} \mathrm{(Spectrum,} \mathrm{Inc.).} \mathrm{Oospores} \mathrm{caught} \mathrm{on}$ the $20-\mu \mathrm{m}$ filter were used in the following studies.

Survival of oospores in the field. Four soils (Table 1) were collected from pumpkin fields in Illinois from 1 to 5 September 2004, and stored at $4^{\circ} \mathrm{C}$ until they were used. Soils were air dried on a laboratory bench $\left(22^{\circ} \mathrm{C}\right)$ for 14 days, then passed through a $2 \mathrm{~mm}$ 
pore-size sieve. Samples of the dry soils were autoclaved twice (3 days apart), each at $157^{\circ} \mathrm{C}$ for $1 \mathrm{~h}$. Ten days after the last autoclaving, soil samples were infested with the oospores of $P$. capsici produced in vitro to give a density of $5 \times 10^{3}$ oospores/g of dry soil. Soil samples were infested by adding an aliquot of a spore suspension of $5 \times 10^{4}$ oospores $/ \mathrm{ml}$ sterilized-distilled water (SDW) to airdried soil, after which the soil was mixed thoroughly. The moisture content of all soils was equilibrated to $-0.3 \mathrm{MPa}$ by adding SDW water (18).

Samples $(25 \mathrm{~g})$ of the infested soil were placed in bags constructed from 15- $\mu$ m polyester-mesh (Spectrum Laboratories, Inc.), and the bags were sealed with hot melt glue. For each soil type, three bags containing infested soil were placed within a PVC tube (36.8 $\mathrm{cm}$ long by $15.3 \mathrm{~cm}$ in diameter) at depths of 2, 10, and 25 $\mathrm{cm}$, as the tube was filled with the same soil (without oospores) that was placed in the bags. A cap made of PVC couplings, covered with one layer of $15-\mu \mathrm{m}$ polyester mesh and one layer of aluminum window screening mesh, was glued firmly on each end of each tube. The caps allowed moisture from rain or melting snow to penetrate soil in the tube. For each soil source, 24 PVC tubes were prepared. The tubes were placed vertically in holes dug on a $1-\mathrm{m}$ grid in a secured area at the University of Illinois Vegetable Research Farm in Champaign $\left(40^{\circ} 04.612^{\prime} \mathrm{N}\right.$; $88^{\circ} 14.371^{\prime} \mathrm{W}$; elevation: $220.5 \mathrm{~m}$ ) on 4 October 2004. Noninfested, autoclaved samples $(25 \mathrm{~g})$ of soil collected from the field in Champaign County (the same field as the experiment location) were placed in the polyester-mesh bags; the bags were placed at depths of 2, 10, and 25 $\mathrm{cm}$ in PVC tubes; and the tubes were buried similarly to the control treatment. The experiment was set up as a randomized completeblock, split-plot design with three replications. Soil source was the main plot treatment, soil depth the subplot treatment, and duration of burial a repeated measure. Temperature was recorded hourly, using Watchdog Logger (Model 400; Spectrum Technologies, Inc.) sensors placed at the soil surface and within a soil-filled PVC tube at depths of 2,10 , and $25 \mathrm{~cm}$.

Also, the following soil samples from the field in Champaign, IL were prepared for comparison of oospore survival in the field versus at room temperature in the laboratory: (i) three PVC tubes (of the same dimensions described above) containing $P$. capsici-infested soil samples at depths of 2,10 , and $25 \mathrm{~cm}$ were buried vertically in the field for oospore recovery 1 month after incorporation; and (ii) 15 mesh bags with $P$. capsici-infested soil samples were prepared and placed on the soil surface near the PVC tubes containing soil samples from the field in Champaign.

Initial data on recovery and germination of oospores in the soil samples were collected within $24 \mathrm{~h}$ of incorporating oospores into the soils on 4 October 2004 (1 Day data), using the procedures developed by Pavon et al. (27). In January, April, and October 2005; October 2006; April and October 2007; and October 2008, three replicate tubes of each soil source were assayed for recovery and germination of $P$. capsici oospores. In addition, infested samples of the Champaign soil in three additional PVC tubes were assayed in November 2004 to compare with soil samples placed on the soil surface and in the laboratory. Samples incubated on the soil surface were processed in November 2004; January, April, and October 2005; and October 2006.

Each soil sample was air dried at room temperature for 2 days before a 10-g sample was processed for oospore extraction (27). Two 10-g samples were processed from each bag. Each 10-g soil sample was suspended in $400 \mathrm{ml}$ of tap water with two drops of Tween 20, and shaken for $5 \mathrm{~min}$ by hand. The soil suspension was then passed through 106-, 63-, and 38- $\mu$ m pore-size metal sieves, the sieves were washed using tap water, and the filtrate was collected. This suspension was then passed through a $20-\mu \mathrm{m}$ mesh filter. The materials caught on the $20-\mu \mathrm{m}$ mesh were washed into two $50-\mathrm{ml}$ centrifuge tubes and spun for $4 \min (900 \times g)$ using a bench-top centrifuge (Centra-CL2; International Equipment Co.). The supernatant was discarded and the pellet resuspended in $30 \mathrm{ml}$ of a $1.6 \mathrm{M}$ sucrose solution. This suspension was then centrifuged for $45 \mathrm{~s}(190 \times g)$ and the resulting supernatant was passed through the $20-\mu \mathrm{m}$ mesh. The pellet was resuspended in the sucrose solution and centrifuged again $(45 \mathrm{~s}, 190 \times g)$. This procedure was repeated five more times (27). The materials caught on the $20-\mu \mathrm{m}$ mesh were washed into a 50-ml centrifuge tube and spun for 4 min $(900 \times g)$. The pellet was resuspended in $1 \mathrm{ml}$ of distilled water. The oospores were enumerated on a hemocytometer using light microscopy. Four oospore counts for each soil sample were carried out, and the percentage of survived oospores was calculated by comparing with the initial oospore concentration incorporated in October 2004.

Oospore survival in the laboratory. The silt clay soil from Champaign was used to study survival of $P$. capsici oospores at room temperature in a laboratory compared with survival in the field. Soil samples with the in-vitro-produced $P$. capsici oospores $\left(5 \times 10^{3}\right.$ oospores/g of dry soil $)$ in $15-\mu \mathrm{m}$ polyester mesh bags were prepared as described previously. A bag containing infested soil was placed within each PVC tube at depths of 2, 10, and 25 $\mathrm{cm}$, as the tube was filled with noninfested soil from Champaign. The tubes were capped as described previously and stored in the laboratory $\left(40^{\circ} 04.624 \mathrm{~N}^{\prime} ; 88^{\circ} 13.446 \mathrm{~W}^{\prime}\right.$; elevation: $\left.255.6 \mathrm{~m}\right)$ at an average air temperature of $22^{\circ} \mathrm{C}$. In November 2004; January, April, and October 2005; and October 2006, bags in each of three replicate tubes were assayed for recovery and germination of $P$. capsici oospores.

Oospore germination. The extracted oospores were tested for germination on semiselective agar medium PARP (26) in petri plates $(90 \mathrm{~mm}$ in diameter). The spores were first treated with $0.1 \% \mathrm{KMnO}_{4}$ for 10 min $(1,27)$ and washed three times with SDW, and $0.2 \mathrm{ml}$ of the oospore suspension (containing 50 oospores) was spread on the surface of each plate of PARP medium. Four plates were used for each treatment (depths of burial and laboratory versus field storage) at each extraction date. If number of extracted oospores from a treatment was fewer than 200, all extracted oospores were plated for germination. The plates were incubated at $24^{\circ} \mathrm{C}$ in the dark for 9 days, at which time the percentage of germinated spore was determined. An oospore with a germ tube at least twice as long as the diameter of the spore was considered germinated. A 5-mm-diameter plug of the colony of each germinated oospore was transferred onto lima bean agar (LBA) (16) and grown at $24^{\circ} \mathrm{C}$ for 5 days, and the culture was examined for mycelial growth and sporangia production. Five germinated oospores from each soil treatment for each duration of burial were examined for production of mycelia and sporangia on LBA.

Oospore viability. A mixture of zoospores produced by five germinated oospores from each soil treatment for each duration of burial was tested for virulence on 'California Wonder' bell pepper in a greenhouse using the method reported by Islam et al. (16). Ten 6 -week-old pepper plants were inoculated with each mixed zoo-

Table 1. Soils used for determining survival of oospores of Phytophthora capsici in soil

\begin{tabular}{|c|c|c|c|c|c|c|c|}
\hline Soil texture & Location $^{y}$ & Soil pH & Organic matter $(\%)$ & Sand $(\%)$ & Silt $(\%)$ & Clay $(\%)$ & Soil weight ${ }^{z}$ \\
\hline Silt clay & Champaign & 7.3 & 5.3 & 7 & 65 & 28 & 7.8 \\
\hline Silt loam & Collinsville & 8.7 & 2.3 & 33 & 55 & 12 & 8.5 \\
\hline Silt loam & Pekin & 6.5 & 4.6 & 24 & 55 & 21 & 8.1 \\
\hline Silt loam & Shawneetown & 5.9 & 2.5 & 18 & 69 & 13 & 8.1 \\
\hline
\end{tabular}

y Nearest town in Illinois. Champaign is in Champaign County, Pekin is in Tazewell County, Shawneetown is in Gallatin County, and Collinsville is in Madison County.

z Oven-dried soil weight of $10 \mathrm{~g}$ of air-dried soil. 
spore inoculum. The bell pepper seed were sown in 10-cm-diameter plastic pots (one seed/pot) containing a steamed potting mix (soil/peat/perlite at 2:1:1) and grown in a greenhouse at 23 to $25^{\circ} \mathrm{C}$. Six-week-old seedlings were inoculated by adding $5 \mathrm{ml}$ of the zoospore suspension $\left(2 \times 10^{5}\right.$ spores/ml of SDW) onto the soil surface around the stem of each plant (16). Each control plant received $5 \mathrm{ml}$ of SDW. Plants were watered to saturation of the soil in the pot $1 \mathrm{~h}$ prior to inoculation to keep the soil wet for zoospore survival. After inoculation, the plants were watered again to soil saturation. Plants were kept on the greenhouse bench for 3 weeks. Beginning on the fourth day after inoculation, plants were checked every day for 15 successive days for seedling death and other symptoms typically caused by $P$. capsici.

Data analysis. Data were analyzed using the procedures for GLM and MIXED models of SAS 9.3 (SAS Institute). Because no oospores were extracted from control soil samples, the data for those control treatments were not included in the analyses. Means of treatments were compared using Fischer's protected least significant difference at $P=0.05$ (25).

\section{Results}

Environmental conditions. From 4 October 2004 to 31 December 2008, minimum, maximum, and mean temperatures on the soil surface and at 2-, 10-, and 25-cm soil depths were -12.1, 37.1, and $10.6^{\circ} \mathrm{C} ;-10.6, .5$, and $10.5^{\circ} \mathrm{C} ;-9.5,33.7$, and $11.0^{\circ} \mathrm{C}$; and -5.5 , 31.5 , and $12.3^{\circ} \mathrm{C}$, respectively. Number of days with freezing temperature (mean daily temperature $\leq 0^{\circ} \mathrm{C}$ ) on the soil surface and at $2-, 10-$, and $25-\mathrm{cm}$ depths was $231,206,175$, and 77 , respectively (Fig. 1). Snow cover at the site started from the beginning of December through the middle of April each year but snow cover did not last for more than a few days after each snowfall. Daytime average temperatures at the site from the middle of May through the middle of October of each year were $>17^{\circ} \mathrm{C}$.

Recovery and germination of oospores. Overall, oospore recovery was not affected significantly by soil type (Table 2 ) or the depth of burial in the soil. However, 24 months after incorporation of oospores into the soils, oospore recovery from the silt loam soil from Collinsville was significantly $(P=0.04)$ greater than oospore recovery from the other three soils. Similarly, 36 months after incorporation, oospore recovery from the silt loam soil from Pekin was significantly $(P=0.05)$ greater than oospore recovery from the silt loam soil from Shawneetown but not from the silt clay and silt loam soils form Champaign and Collinsville, respectively.

Oospore recovery was affected significantly $(P=0.001)$ by the duration of burial (Table 2). The mean rate of oospores recovered from soil samples was 61.06, 16.69, 10.28, 1.05, 0.30, 0.06, 0.05, and $0.004 \%$ after 1 day and $3,6,12,24,30,36$, and 48 months, respectively, after incorporation of oospores into the soil. There were significant $(P=0.01)$ differences in the percentage of oospores recovered from the four soil types after 1 day and 3, 6, and 12 months of incubation but no difference in mean recovery from 12 to 48 months (Table 2).

Overall, the percentage of the recovered oospores that germinated was not significantly affected by soil type (Table 2 ) or depth of burial in soil. However, there were significant $(P \leq 0.05)$ differences in the percentage of germinated oospores recovered from different soils 1 day and 3, 6, 12, and 24 months after incorporation of oospores into the soils but no difference in germination of oospores recovered from different soils after 30, 36, or 48 months (Table 2). Oospore germination was significantly $(P=0.001)$ affected by the duration of oospore burial (Table 2). The mean rate of germination of oospores recovered from all four soils was 47.17 , $30.53,21.33,15.64,7.42,2.67,2.61$, and $0.00 \%$ after 1 day and 3,6 , 12, 24, 30, and 48 months, respectively, after incorporation of oospores into the soil. There were significant $(P=0.001)$ differences in the mean percentage germination of oospores recovered from all four soils 1 day and 3,6, 12, 24, and 30 months from oospore incorporation but no difference from 30 to 48 months (Table 2).

Comparison of oospore survival in a laboratory versus in a field. One month after incorporation of oospores into the soil, the

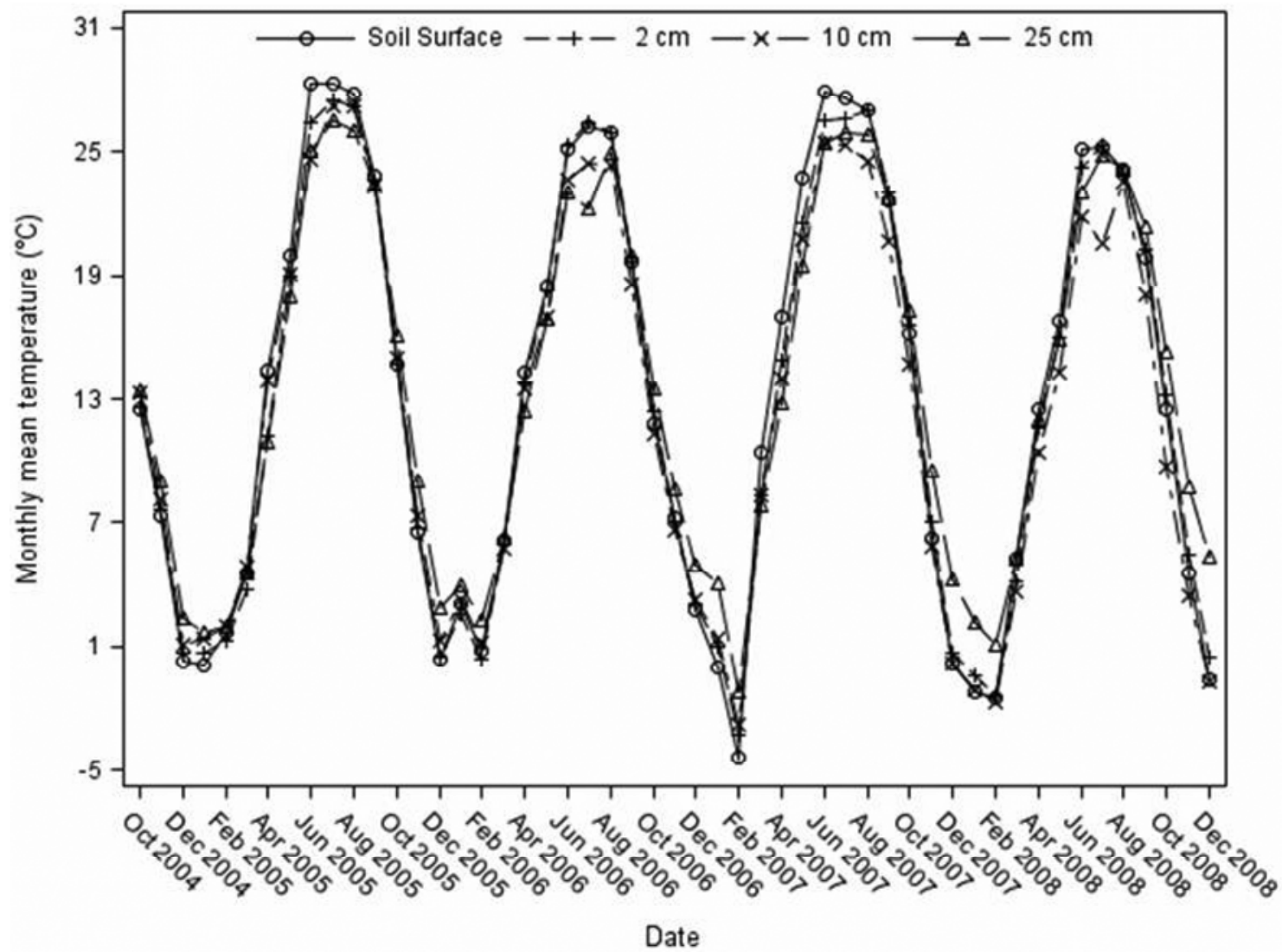

Fig. 1. Monthly mean temperature $\left({ }^{\circ} \mathrm{C}\right)$ at the soil surface and at 2-, 10-, and $25-\mathrm{cm}$ depths at the University of Illinois Vegetable Research Farm in Champaign, IL from October 2004 to December 2008. 
soil samples stored in the laboratory were dry. The mean percentage of oospores recovered from soil samples stored in the laboratory was significantly $(P=0.01)$ greater than the mean percentage of oospores recovered from soil samples in the field (Table 3). Oospore recovery was also affected significantly $(P=0.001)$ by the duration of storage (Table 3). Twenty-four months after incorporation of oospores into the soil, $26.52 \%$ of oospores were recovered from soil samples that had been stored in the laboratory, whereas an average of $0.12 \%$ of oospores were recovered from soil samples stored in the field. Overall, the percentages of oospores recovered from soil samples placed on the soil surface or buried 2, 10 , or $25 \mathrm{~cm}$ deep were not significantly different, except 3 months after incorporation, when the percentage of oospores recovered from soil samples buried $25 \mathrm{~cm}$ deep was significantly $(P=0.04)$ greater than the recovery from samples placed on the soil surface but not different than the recovery from soil samples buried 2 or $10 \mathrm{~cm}$ deep.

Overall, oospore germination was not affected significantly by the location of soil sample storage (laboratory versus field). However, there were significant $(P \leq 0.05)$ differences in the mean percentage of germinated oospores recovered from samples stored in the laboratory, placed on the soil surface, or buried 2, 10, and 25 $\mathrm{cm}$ deep at each of the durations of storage from 3 to 24 months (Table 3). The mean percentage germination of oospores recovered from soil samples buried 2,10 , or $25 \mathrm{~cm}$ deep in the field was not significantly $(P=0.05)$ different at each of the durations of storage (Table 3). Overall, the mean percentage of germinated oospores recovered from samples stored in the laboratory and field was significantly $(P=0.001)$ affected by the duration of oospore storage. The mean rate of oospore germination was $43.13,35.87,28.33$, 15.40 , and $6.47 \%$ after $1,3,6,12$, and 24 months, respectively, after incorporation of oospore into the soil (Table 3).

Oospore viability. All germinated oospores produced mycelia, sporangia, and zoospores. All of the inoculated pepper plants developed symptoms of infection. Plants defoliated within 10 days of inoculation and developed necrotic lesions at the crown, followed by wilting and death of the plants within 3 weeks of inoculation. Control plants did not develop any symptoms. P. capsici was reisolated from inoculated plants.

\section{Discussion}

The combination of sieving followed by density separation in a sucrose solution has long been used to extract spores of Plasmodi- ophora brassica (7), mycorrhizal fungi (15), bunt fungi (3), and nematodes (17) from soil. To our knowledge, this is the first report of studying survival of oospores of a Phytophthora sp. in soil using sucrose density to extract oospores from soil. Using mesh bags and PVC tubes to assess survival of oospores over a period of 48 months provided several advantages compared with methods used by other investigators, including: (i) the method enabled the study of survival of a high density of oospores in soil and (ii) provided the ability to assess survival of oospores in different soil types at a single site; (iii) damage of oospores by animals and plants was avoided; and (iv) production of additional oospores due to plant infection in the soil during storage was prevented. Oospores appear not to have been damaged by either the sieving steps or the sucrose solution during the extraction process from soil, as demonstrated by Pavon et al. (27). This study suggests that the method probably can be used to assess survival of oospores of other Phytophthora spp. in soil.

P. capsici oospores survived more than 36 months in all four soil types tested, and less than $0.01 \%$ of oospores were extracted from three of the four soils after 48 months. The results concur with previous reports $(6,10)$ that $P$. capsici oospores can survive for several years in soil. However, the results of this study showed that, although few oospores survived as long as 48 months in soil, they were not viable by 48 months. Similar studies in other vegetableproducing areas with different environmental conditions would verify survival and viability of oospores of $P$. capsici in diverse environments. Overall, results of this study showed that soil types evaluated did not affect survival or germination of $P$. capsici oospores significantly. Because soil types used in this study were only silt clay and silt loam, studies with more diverse soil textures may result in different findings. Survival of $P$. capsici oospores in other areas may also be affected by soil temperature and moisture.

In this study, germinated oospores recovered from soil produced mycelia, sporangia, and zoospores. A mixed inoculum of zoospores produced from five germinated oospores from each soil type and applied to bell pepper plants in a greenhouse resulted in infection and symptom development. This indicates that $P$. capsici oospores that germinate and produce sporangia and zoospores are likely to be able to infect host plants such as pepper and cucurbits.

By 1 month after incorporation of oospores into the soil, the soil samples stored in the laboratory were very dry and the percentage of oospores recovered from these samples was significantly greater

Table 2. Recovery and germination of Phytophthora capsici oospores from four soil samples buried at the University of Illinois Vegetable Research Farm in Champaign from 2004 to 2008

\begin{tabular}{|c|c|c|c|c|c|c|c|c|c|}
\hline \multirow[b]{2}{*}{ Oospore trait, soil texture } & \multicolumn{8}{|c|}{ Sampling date (duration after burial of oospores) ${ }^{w}$} & \multirow[b]{2}{*}{ Mean } \\
\hline & $\begin{array}{c}\text { October } \\
2004 \\
\text { (1 day) }\end{array}$ & $\begin{array}{c}\text { January } \\
2005 \\
\text { (3 months) }\end{array}$ & $\begin{array}{c}\text { April } \\
2005 \\
\text { (6 months) }\end{array}$ & $\begin{array}{c}\text { October } \\
2005 \\
\text { (12 months) }\end{array}$ & $\begin{array}{c}\text { October } \\
2006 \\
\text { (24 months) }\end{array}$ & $\begin{array}{c}\text { April } \\
2007 \\
\text { (30 months) }\end{array}$ & $\begin{array}{c}\text { October } \\
2007 \\
\text { (36 months) }\end{array}$ & $\begin{array}{c}\text { October } \\
2008 \\
\text { (48 months) } \\
\end{array}$ & \\
\hline \multicolumn{10}{|l|}{ Oospore recovery $(\%)^{\mathrm{x}}$} \\
\hline Silt clay (Champaign) & $58.67 \mathrm{a}$ & $20.37 \mathrm{a}$ & $13.52 \mathrm{a}$ & $1.09 \mathrm{a}$ & $0.12 \mathrm{~b}$ & $0.05 \mathrm{a}$ & $0.06 \mathrm{ab}$ & $0.006 \mathrm{a}$ & $11.74 \mathrm{a}$ \\
\hline Silt loam (Collinsville) & $60.56 \mathrm{a}$ & $12.78 \mathrm{a}$ & $8.52 \mathrm{a}$ & $0.81 \mathrm{a}$ & $0.78 \mathrm{a}$ & $0.09 \mathrm{a}$ & $0.05 \mathrm{ab}$ & $0.006 \mathrm{a}$ & $10.45 \mathrm{a}$ \\
\hline Silt loam (Pekin) & $65.56 \mathrm{a}$ & $18.06 \mathrm{a}$ & $10.00 \mathrm{a}$ & $1.95 \mathrm{a}$ & $0.17 \mathrm{~b}$ & $0.09 \mathrm{a}$ & $0.08 \mathrm{a}$ & $0.004 \mathrm{a}$ & $11.99 \mathrm{a}$ \\
\hline Silt loam (Shawneetown) & $59.45 \mathrm{a}$ & $15.56 \mathrm{a}$ & $9.07 \mathrm{a}$ & $0.33 \mathrm{a}$ & $0.14 \mathrm{~b}$ & $0.02 \mathrm{a}$ & $0.02 \mathrm{~b}$ & $0.000 \mathrm{a}$ & $10.57 \mathrm{a}$ \\
\hline Mean & $61.06(\mathrm{~A})$ & 16.69 (B) & $10.28(\mathrm{C})$ & 1.05 (D) & $0.30(\mathrm{D})$ & 0.06 (D) & $0.05(\mathrm{D})$ & 0.004 (D) & 11.19 \\
\hline \multicolumn{10}{|l|}{ Oospore germination $(\%)^{\mathrm{y}}$} \\
\hline Original oospores ${ }^{\mathrm{z}}$ & 44.50 & & & & & & & & \\
\hline Silt clay (Champaign) & $52.33 \mathrm{a}$ & $34.44 \mathrm{a}$ & 24.89 a & $11.33 \mathrm{~b}$ & $3.11 \mathrm{~b}$ & $1.56 \mathrm{a}$ & $1.89 \mathrm{a}$ & $0.000 \mathrm{a}$ & $16.19 \mathrm{a}$ \\
\hline Silt loam (Collinsville) & $48.33 \mathrm{ab}$ & $31.44 \mathrm{ab}$ & $20.67 \mathrm{bc}$ & $24.11 \mathrm{a}$ & $3.33 \mathrm{~b}$ & $3.78 \mathrm{a}$ & $2.22 \mathrm{a}$ & $0.000 \mathrm{a}$ & $16.74 \mathrm{a}$ \\
\hline Silt loam (Pekin) & $38.33 \mathrm{~b}$ & $26.22 \mathrm{c}$ & $17.78 \mathrm{c}$ & $11.78 \mathrm{~b}$ & $14.00 \mathrm{a}$ & $2.89 \mathrm{a}$ & $4.00 \mathrm{a}$ & $0.000 \mathrm{a}$ & $14.38 \mathrm{a}$ \\
\hline Silt loam (Shawneetown) & $49.67 \mathrm{a}$ & $30.00 \mathrm{bc}$ & $22.00 \mathrm{ab}$ & $15.33 \mathrm{~b}$ & $9.22 \mathrm{ab}$ & $2.44 \mathrm{a}$ & $2.33 \mathrm{a}$ & $0.000 \mathrm{a}$ & $16.38 \mathrm{a}$ \\
\hline Mean & $47.17(\mathrm{~A})$ & $30.53(\mathrm{~B})$ & $21.33(\mathrm{C})$ & $15.64(\mathrm{D})$ & $7.42(\mathrm{E})$ & $2.67(\mathrm{~F})$ & $2.61(\mathrm{~F})$ & $0.000(\mathrm{~F})$ & 15.92 \\
\hline
\end{tabular}

${ }^{\text {w}}$ Mean values within a row with an uppercase letter in common (inside parentheses) are not significantly different according to Fischer's protected least significant difference $(\mathrm{LSD})(P=0.05)$.

${ }^{\mathrm{x}}$ In October 2004, $5 \times 10^{3}$ oospores/g of soil were incorporated into each soil. Oospores were extracted from 10-g soil samples. Each value represents the mean of 18 processed soil samples (two samples from each replication of each burial depth). In each column, values with a letter in common are not significantly different according to Fisher's protected LSD $(P=0.05)$.

${ }^{y}$ Each value represents the mean of 200 oospores (or all of the oospores if there were fewer than 200) extracted from soil samples from the same site. In each column, values with a letter in common are not significantly different according to Fisher's protected LSD $(P=0.05)$.

${ }^{\mathrm{z}}$ Oospores sampled immediately before incorporating into the soil. 
Table 3. Recovery and germination of Phytophthora capsici oospores in a silt clay soil sampled from the University of Illinois Vegetable Research Farm in Champaign and incubated in the field or at a constant temperature from 2004 to 2006

\begin{tabular}{|c|c|c|c|c|c|c|}
\hline \multirow[b]{2}{*}{ Trait, location $^{\mathrm{x}}$} & \multicolumn{5}{|c|}{ Sampling date (duration after storage of oospores) ${ }^{\mathrm{w}}$} & \multirow[b]{2}{*}{ Mean } \\
\hline & $\begin{array}{c}\text { November } 2004 \\
\text { (1 months) }\end{array}$ & $\begin{array}{c}\text { January } 2005 \\
\text { (3 months) }\end{array}$ & $\begin{array}{l}\text { April } 2005 \\
\text { (6 months) }\end{array}$ & $\begin{array}{c}\text { October } 2005 \\
(12 \text { months }) \\
\end{array}$ & $\begin{array}{c}\text { October } 2006 \\
(24 \text { months }) \\
\end{array}$ & \\
\hline \multicolumn{7}{|c|}{$\begin{array}{l}\text { Oospore recovery }(\%)^{y} \\
\text {. }\end{array}$} \\
\hline Room $\left(22^{\circ} \mathrm{C}\right)$ & $53.89 \mathrm{a}$ & $42.22 \mathrm{a}$ & $34.45 \mathrm{a}$ & $30.28 \mathrm{a}$ & $26.52 \mathrm{a}$ & $37.47 a$ \\
\hline Soil surface & $28.89 \mathrm{~b}$ & $7.78 \mathrm{c}$ & $4.45 \mathrm{~b}$ & $2.94 \mathrm{~b}$ & $0.11 \mathrm{~b}$ & $8.83 \mathrm{~b}$ \\
\hline Soil, $2 \mathrm{~cm}$ & $40.00 \mathrm{ab}$ & $15.56 \mathrm{bc}$ & $16.11 \mathrm{~b}$ & $2.26 \mathrm{~b}$ & $0.20 \mathrm{~b}$ & $14.83 \mathrm{~b}$ \\
\hline Soil, $10 \mathrm{~cm}$ & $22.78 \mathrm{~b}$ & $21.11 \mathrm{bc}$ & $10.56 \mathrm{~b}$ & $0.43 \mathrm{~b}$ & $0.09 \mathrm{~b}$ & $11.00 \mathrm{~b}$ \\
\hline Soil, $25 \mathrm{~cm}$ & $38.33 \mathrm{ab}$ & $24.44 \mathrm{~b}$ & $13.89 \mathrm{~b}$ & $0.58 \mathrm{~b}$ & $0.07 \mathrm{~b}$ & $15.46 \mathrm{~b}$ \\
\hline Mean & $36.78(\mathrm{~A})$ & $22.22(\mathrm{~B})$ & 15.89 (B) & $7.30(\mathrm{C})$ & $5.40(\mathrm{C})$ & 17.52 \\
\hline \multicolumn{7}{|c|}{ Oospore germination $(\%)^{\mathrm{z}}$} \\
\hline Room $\left(22^{\circ} \mathrm{C}\right)$ & $44.67 \mathrm{a}$ & $40.67 \mathrm{a}$ & $35.00 \mathrm{a}$ & $22.33 \mathrm{a}$ & $9.00 \mathrm{ab}$ & $30.33 a$ \\
\hline Soil surface & $44.00 \mathrm{a}$ & $35.33 a b$ & $32.00 \mathrm{ab}$ & $20.67 \mathrm{a}$ & $14.00 \mathrm{a}$ & $29.20 \mathrm{a}$ \\
\hline Soil, $2 \mathrm{~cm}$ & $40.00 \mathrm{a}$ & $31.33 \mathrm{~b}$ & $22.67 \mathrm{c}$ & $14.00 \mathrm{ab}$ & $1.33 \mathrm{~b}$ & $21.87 a$ \\
\hline Soil, $10 \mathrm{~cm}$ & $44.33 \mathrm{a}$ & $38.00 \mathrm{ab}$ & $27.33 \mathrm{abc}$ & $11.67 \mathrm{ab}$ & $4.67 \mathrm{~b}$ & $25.20 \mathrm{a}$ \\
\hline Soil, $25 \mathrm{~cm}$ & $42.67 \mathrm{a}$ & $34.00 \mathrm{ab}$ & $24.67 \mathrm{bc}$ & $8.33 \mathrm{~b}$ & $3.33 \mathrm{~b}$ & $22.60 a$ \\
\hline Mean & $43.13(\mathrm{~A})$ & $35.87(\mathrm{~B})$ & $28.33(\mathrm{C})$ & $15.40(\mathrm{D})$ & $6.47(\mathrm{E})$ & 25.84 \\
\hline
\end{tabular}

${ }^{\text {w}}$ Mean values within a row with an uppercase letter in common (inside parentheses) are not significantly different according to Fisher's protected least significant difference (LSD) $(P=0.05)$.

${ }^{x}$ Oospore trait measured and location of oospore storage.

${ }^{y}$ In October 2004, $5 \times 10^{3}$ oospores/g of soil were incorporated into the soil. Oospores were extracted from 10-g soil samples. Each value represents the mean of six processed soil samples (two samples from each replication). In each column, values with a letter in common are not significantly different according to Fisher's protected LSD $(P=0.05)$.

${ }^{\mathrm{z}}$ Each value represents the mean of 200 oospores extracted from soil samples from the same site. In each column, values with a letter in common are not significantly different according to Fisher's protected LSD $(P=0.05)$.

than those from soil samples in the field. The results concur with the finding by Bowers et al. (6) that P. capsici oospores survive longer in dry soil than wet soil. However, the study by Bowers et al. (6) was over a 16-week duration, whereas this study lasted for 24 months. Survival studies over periods longer than 24 months may show a faster decrease in survival or viability of oospores in dry soils. In this study, oospore germination decreased from $22.33 \%$ after 12 months to $9.00 \%$ after 24 months of storage in soil maintained at room temperature.

The results of this study are expected to provide valuable information for determining appropriate crop rotations for management of $P$. capsici in vegetables. Crop rotation is an effective method for management of some soilborne plant diseases (13). However, effective crop rotations for the management of $P$. capsici are still being established. To establish effective crop rotations for management of a specific plant pathogen, determining host-range and duration of survival of the pathogen in various soil types where the crop is grown is essential. Previous studies $(8-10,30,31)$ have provided information on the host-range of $P$. capsici. Pavon et al. (27) developed the sieving and sucrose-centrifugation method used in this study for determining survival of $P$. capsici oospores. As a result, it appears that a 4-year rotation with nonhost crops, coupled with effective weed control and avoiding the use of irrigation water contaminated with $P$. capsici, should provide effective management of $P$. capsici in susceptible vegetables in central Illinois. In order to minimize survival of $P$. capsici in the field, complete weed control is necessary (31). Previously reported failures to manage $P$. capsici in vegetables following rotations with nonhost crops for 5 years or longer $(20,21)$ may be due, in part, to survival of $P$. capsici on weeds, as reported by Tian and Babadoost (31).

This study was conducted using autoclaved soils. Although soil microorganisms may have penetrated the soil inside the PVC tubes, facilitated by moisture from rain and melting snow, the effects of soil organisms on survival of oospores in soil were not measured in this study. A study on effects of soilborne fauna, flora, and plant material on survival of $P$. capsici oospores would help to determine the influence of these factors on survival of this important plant pathogen in soils.

\section{Acknowledgments}

This research was supported, in part, by funds from the USDA-CREES-NCRSARE agreement 2003-38640-13225, and Nestle Food Company.

\section{Literature Cited}

1. Ann, P. J., and Ko, W. H. 1988. Induction of oospore germination of Phytophthora parasitica. Phytopathology 78:335-338.

2. Babadoost, M., and Islam, S. Z. 2003. Fungicide seed treatment effects on seedling damping-off of pumpkin caused by Phytophthora capsici. Plant Dis. 87:63-68.

3. Babadoost, M., and Mathre, D. E. 1998. A method for extraction and enumeration of teliospores of Tilletia indica, T. controversa, and T. barclayana in soil. Plant Dis. 82:1357-1361.

4. Babadoost, M., and Pavon, C. 2009. Survival of Phytophthora capsici in soil. Page 2 in: Proc. 2nd Int. Phytophthora capsici Conf. Duck Cay, FL.

5. Babadoost, M., and Zitter, T. A. 2009. Fruit rots of pumpkin: a serious threat to the pumpkin industry. Plant Dis. 93:772-782.

6. Bowers, J. H., and Mitchell, D. J. 1990. Effect of soil-water matric potential and periodic flooding on mortality of pepper caused by Phytophthora capsici. Phytopathology 80:1447-1450.

7. Buczacki, S. T., and Ockendon, J. G. 1978. A method for the extraction and enumeration of resting spores of Plasmodiophora brassica from infested soil. Ann. Appl. Biol. 88:363-367.

8. Davidson, C. R., Carroll, R. B., Evans, T. A., Mulrooney, R. P., and Kim, S. H. 2002. First report of Phytophthora capsici infecting lima bean (Phaseolus lunatus) in the Mid-Atlantic Region. Plant Dis. 86:1049.

9. Erwin, D. C., and Ribeiro, O. K. 1996. Phytophthora Diseases Worldwide. American Phytopathological Society, St. Paul, MN.

10. French-Monar, R. D., Jones, J. B., and Roberts, P. D. 2006. Characterization of Phytophthora capsici associated with roots of weeds on Florida vegetable farms. Plant Dis. 90:345-350.

11. Granke, L. L., Quesada-Ocampo, L. M., Lamour, K., and Hausbeck, M. K. 2012. Advances in research on Phytophthora capsici on vegetable crops in the United States. Plant Dis. 95:1588-1600.

12. Gubler, W. D., and Davis, R. M. 1996. Phytophthora crown and root rot. Pages 19-20 in: Compendium of Cucurbit Diseases. T. A. Zitter, D. L. Hopkins, and C. E. Thomas, eds. American Phytopathological Society, St. Paul, MN.

13. Hausbeck, M. K., and Lamour, K. H. 2004. Phytophthora capsici on vegetable crops: research progress and management challenges. Plant Dis. 88:1292-1303.

14. Hwang, B. K., and Kim, C. H. 1995. Phytophthora blight of pepper and its control in Korea. Plant Dis. 79:221-227.

15. Ianson, D. C., and Allen, M. F. 1986. The effects of soil texture on extraction of vesicular-arbuscular mycorrhizal fungal spores from arid sites. Mycology 78:164-168.

16. Islam, S. Z., Babadoost, M., Lambert, K. N., Ndeme, A., and Fouly, H. M. 2004. Characterization of Phytophthora capsici isolates from processing pumpkin in Illinois. Plant Dis. 89:191-197.

17. Jenkins, W. R. 1964. A rapid centrifugal-flotation technique for separating nematodes from soil. Plant Dis. Rep. 48:692.

18. Klute, A. 1986. Water retention: laboratory methods. Pages 635-662 in: Methods of Soil Analysis, Physical and Mineralogical Methods, Part 1, 2nd ed. A. Klute, ed. American Society of Agronomy, Madison, WI.

19. Kousik, C. S., Thies, J. A., and Harrison, H. F. 2011. Effect of Actigard and 
other new fungicides on Phytophthora fruit rot of watermelon. Page 9 in: Proc. 3rd Int. Phytophthora capsici Conf. Duck Cay, FL.

20. Lamour, K. H., and Hausbeck, M. K. 2001. Investigating the spatiotemporal genetic structure of Phytophthora capsici in Michigan. Phytopathology 91:973-980.

21. Lamour, K. H., and Hausbeck, M. K. 2003. Effect of crop rotation on the survival of Phytophthora capsici in Michigan. Plant Dis. 87:841-845.

22. Larkin, R. P., Ristaino, J. B., and Campbell, C. L. 1995. Detection and quantification of Phytophthora capsici in soil. Phytopathology 85:10571063.

23. Lee, B. K., Kim, B. S., Chang, S. W., and Hwang, B. K. 2001. Aggressiveness to pumpkin cultivars of isolates of Phytophthora capsici from pumpkin and pepper. Plant Dis. 85:497-500.

24. Leonian, L. H. 1922. Stem and fruit blight of peppers caused by Phytophthora capsici sp. nov. Phytopathology 12:401-408.

25. Ott, R. L., and Longnecker, M. 2001. An Introduction to Statistical Methods and Data Analysis, 5th ed. Duxbury, Pacific Grove, CA.

26. Papavizas, G. C., Bowers, J. H., and Johnston, S. A. 1981. Selective isolation of Phytophthora capsici from soils. Phytopathology 71:129-133.

27. Pavon, C. F., Babadoost, M., and Lambert, K. N. 2008. Quantification of Phytophthora capsici oospores in soil by sieving-centrifugation and realtime polymerase chain reaction. Plant Dis. 92:143-149.

28. Ristaino, J. B. 1990. Intraspecific variation among isolates of Phytophthora capsici from pepper and cucurbit fields in North Carolina. Phytopathology 80:1253-1259.

29. Ristaino, J. B. 2003. Phytophthora blight of peppers. Pages 17-19 in: Compendium of Pepper Diseases. K. Pernezny, P. D. Roberts, J. F. Murphy, and N. P. Goldberg, eds. American Phytopathological Society, St. Paul, MN.

30. Satour, M. M., and Butler, E. E. 1967. A root and crown rot of tomato caused by Phytophthora capsici and P. parasitica. Phytopathology 57:510-515.

31. Tian, D., and Babadoost, M. 2004. Host range of Phytophthora capsici from pumpkin and pathogenicity of isolates. Plant Dis. 88:485-489. 